\title{
Factors Influencing Intention to Stop Smoking in Community in Nagan Raya Aceh, Indonesia
}

\author{
Vera Nazhira Arifin ${ }^{1 *}$, Eva Nursatika ${ }^{1}$, Intan Liana $^{1}$, Febbyola Presilawati $^{1}$, \\ Meutia Zahara $^{2,3}$, Ramadhaniah $^{1}$
}

\author{
${ }^{1}$ Faculty of Public Health, University Muhammadiyah Aceh, Banda Aceh, Indonesia \\ ${ }^{2}$ Postgraduate Program of Public Health, University Muhammadiyah Aceh, Banda Aceh, Indonesia \\ ${ }^{3}$ Department of Biology, Islamic Faculty, University Muhammadiyah Aceh, Banda Aceh, Indonesia \\ Corresponding author. Email: veranazhira13@gmail.com
}

\begin{abstract}
One of the health effort in terms of reducing deaths from cigarettes each year is to limit smoking consumption through increased intention to quit smoking. Basic Health Research Data 2013 shows that the current proportion of smokers in Aceh province is (29.3\%) and the proportion according to smoking habit in Nagan Raya is (21.7\%) consisting of every day smokers $(17.3 \%)$ and periodically smokers $(4.4 \%)$. This study aims to determine the factors that affect the intention to stop smoking in Gampong Kuta Paya Seunagan District Nagan Raya District Year 2015. This research is analytical descriptive with cross sectional design. The data were collected by interview using questionnaire. The population in this study was the entire head of the family who smoked as many as 63 people (Total Sampling). This research was conducted from 27 October to 10 November 2015. Data analysis with Chi Square Test and Logistic Regression. The result of the research shows that the respondent age is less productive (38.1\%), respondents work as self-employed (34,9\%), respondent earn over UMP (76.2\%), respondents smoke filter cigarettes (68.3\%). Respondents had no intention (68.3\%), respondents behave negatively (58.7\%), respondents with negative normative belief $(65.1 \%)$, and respondents with no motivation $(63.5 \%)$. The result of statistic test obtained with no age influence ( $\mathrm{P}$ Value $=0.109)$, income $(\mathrm{P}$ Value $=1,000)$, with intention to stop smoking, and there is influence of attitude ( $\mathrm{P}$ Value $=0.001)$, normative trust $(\mathrm{P}$ Value $=0.010)$ and motivation $(\mathrm{P}$ Value $=0.018)$ with the intention to stop smoking. Attitude is the most influential to intention $(\mathrm{OR}=6.6)$. This research is expected to be an input / information for health agencies and the public in improving the intention to stop smoking in order to reduce the mortality rate from smoking. Keywords: age, income, attitude, normative belief, intention to stop smoking
\end{abstract}

\section{INTRODUCTION}

Smoking is a habit that disturbs health. This fact is undeniable, many diseases have been proven to be a bad result of smoking. Tobacco is a risk factor for various cancers, especially lung cancer, and the risk of heart disease, stroke, respiratory disorders and others [1]. Smoking priority a major health because tobacco is the cause of death of 1 in 10 adults (about 5 million deaths per year) [1].

Based on the results of interviews conducted with 10 smokers active in Kuta Paya village, Seunagan sub- district, Nagan Raya district, it was very difficult to stop smoking, some of them wanted to stop smoking because it was very dangerous to health and some were also motivated by families who still had babies and toddlers but difficult because of dependency, for example, if they do not smoke find it difficult to think and often do not concentrate on doing work, as long as the body is still able to do activities (old age) and the effects of the dangers of smoking have not been felt, they will still smoke, but some of them have also stopped smoking but have failed to influence the surrounding environment which is not supportive for to them stop smoking. Knowledge is about what affects the intention to stop smoking from each individual in particular, so that can be planned activities and activities and organized that can limit smoking [2]. One way to find out this is to conduct research on the factors that influence the intention to stop smoking in the community.

\section{METHOD}


This research analytical descriptive using cross secional Study design is independent and dependent variables investigated or observed at the same time when the study was conducted aiming to determine the factors that affect the intention to stop smoking in public in Kuta Gampong marsh Seunagan Sub Nagan Raya 2015. Techniques sampling with all Inroads as samples used were 63 respondents.

\section{RESULTS AND DISCUSSION}

Based on the results of research that has been done in the Village Kuta Paya District of Seunagan Kabupaten Nagan Raya, on 27 October to November to 10 2015, with the number respond en were 63 respondents shows the results that can be seen in the following table:

Table 1. Effect of Age Factors with Smoking Stop Intention in Respondens in Gampong Kuta Paya, Seunagan District Nagan Raya District

\begin{tabular}{|c|c|c|c|c|c|c|c|c|}
\hline \multirow{3}{*}{ No } & \multirow{3}{*}{ Age } & \multicolumn{4}{|c|}{ Intention } & \multirow{2}{*}{\multicolumn{2}{|c|}{ Total }} & \multirow{3}{*}{$\begin{array}{c}\mathrm{P} \\
\text { value }\end{array}$} \\
\hline & & \multicolumn{2}{|c|}{ Have } & \multicolumn{2}{|c|}{$\begin{array}{l}\text { Do not } \\
\text { have }\end{array}$} & & & \\
\hline & & $\mathrm{N}$ & $\%$ & $\mathrm{n}$ & $\%$ & $\mathrm{~N}$ & $\%$ & \\
\hline 1 & Productive & 2 & 11.8 & 15 & 88.2 & 17 & 100 & \\
\hline 2 & $\begin{array}{l}\text { Less } \\
\text { productive }\end{array}$ & 10 & 41.7 & 14 & 58.3 & 24 & 100 & 0100 \\
\hline 3 & $\begin{array}{l}\text { Not } \\
\text { productive }\end{array}$ & 8 & 36.4 & 14 & 63.6 & 22 & 100 & 0.109 \\
\hline & amount & 20 & 31.7 & 43 & 68.3 & 63 & 100 & \\
\hline
\end{tabular}

Table 1 shows that the higher the respondent's age the desire to stop smoking is lower and those who do not have the intention to quit smoking are higher at $88.2 \%$ of the productive age respondents. Statistical test results also obtained the value of $p$ value $=0.109$ so that it can be seen that the work hypothesis $(\mathrm{Ha})$ is rejected which means there

\begin{tabular}{|c|c|c|c|c|c|c|c|c|}
\hline \multirow{3}{*}{ No } & \multirow{3}{*}{ Attitude } & \multicolumn{4}{|c|}{ Intention } & \multirow{2}{*}{\multicolumn{2}{|c|}{ Total }} & \multirow[t]{3}{*}{ P value } \\
\hline & & \multicolumn{2}{|c|}{ Have } & \multicolumn{2}{|c|}{$\begin{array}{l}\text { Do not } \\
\text { have }\end{array}$} & & & \\
\hline & & $\mathrm{N}$ & $\%$ & $\mathrm{~N}$ & $\%$ & $\mathrm{~N}$ & $\%$ & \\
\hline 1 & Positive & 15 & 57.7 & 11 & 42.3 & 24 & 100 & \multirow{3}{*}{0.001} \\
\hline 2 & Negative & 5 & 13.5 & 32 & 86.5 & 39 & 100 & \\
\hline & amount & 20 & 31.7 & 43 & 68.3 & 63 & 100 & \\
\hline
\end{tabular}

is no effect of age with the intention to stop smoking in the community in Kuta Paya Village, Seunagan District, Nagan Raya Regency in 2015.

Table 2. Attitude Factor with Smoking Stop Intention

Table 2 shows the desire to stop smoking is not affected by income. High income and low income do not have the intention to stop smoking. The higher the income, the less willing to stop smoking $(68.8 \%)$. The statistical test results also obtained the value of $p$ value $=1,000$ so that it can be seen that the work hypothesis $(\mathrm{Ha})$ is rejected which means there is no influence of age with the intention to stop smoking in the community in Kuta, Seunagan District, Nagan Raya Regency in 2015.

Table 3. Effort of Income Factors with Smoking Stop Intention in Respondents in Gampong Kuta Paya District

\begin{tabular}{|c|c|c|c|c|c|c|c|c|}
\hline \multirow{3}{*}{ No } & \multirow{3}{*}{ Income } & \multicolumn{4}{|c|}{ Intention } & \multirow{2}{*}{\multicolumn{2}{|c|}{ Total }} & \multirow{3}{*}{$\begin{array}{c}\mathrm{P} \\
\text { value }\end{array}$} \\
\hline & & \multicolumn{2}{|c|}{ Have } & \multicolumn{2}{|c|}{$\begin{array}{c}\text { Do not } \\
\text { have }\end{array}$} & & & \\
\hline & & $\mathrm{N}$ & $\%$ & $\mathrm{n}$ & $\%$ & $\mathrm{~N}$ & $\%$ & \\
\hline 1 & $\begin{array}{l}\text { Above } \\
\text { UMP }\end{array}$ & 15 & 31.2 & 33 & 68.8 & 48 & 100 & \\
\hline 2 & $\begin{array}{l}\text { Under the } \\
\text { UMP }\end{array}$ & 5 & 33.3 & 10 & 66.7 & 15 & 100 & 1,000 \\
\hline & Amount & 20 & 31.2 & 43 & 68.3 & 63 & 100 & \\
\hline
\end{tabular}

Table 3 shows that respondents who have a positive attitude tend to have an interest in quitting smoking which is $57.7 \%$ while those who have a negative attitude tend not to have the intention to quit smoking which is $86.5 \%$. Statistical test results obtained $\mathrm{p}$ value $=0.001$ so that it can be seen that the work hypothesis (Ha) is accepted which means there is an influence of attitude with the intention to stop smoking in the community in Kuta Paya Village, Seunagan District, Nagan Raya Regency in 2015.

Table 4. Effert of Normative Trust Factors with Smoking Stop Intention in Respondents in Gampong Kuta Paya Kecamatan Seunagan, Nagan Raya District

\begin{tabular}{|c|c|c|c|c|c|c|c|c|}
\hline \multirow{3}{*}{ No } & \multirow{3}{*}{$\begin{array}{c}\text { Normative } \\
\text { belief }\end{array}$} & \multicolumn{4}{|c|}{ Intention } & \multirow{2}{*}{\multicolumn{2}{|c|}{ Total }} & $\mathrm{P}$ \\
\hline & & \multicolumn{2}{|c|}{ Have } & \multicolumn{2}{|c|}{$\begin{array}{c}\text { Do not } \\
\text { have }\end{array}$} & & & \multirow[t]{2}{*}{ value } \\
\hline & & $\mathrm{N}$ & $\%$ & $\mathrm{~N}$ & $\%$ & $\mathrm{~N}$ & $\%$ & \\
\hline 1 & Positive & 12 & 54.5 & 10 & 45.5 & 22 & 100 & \multirow{3}{*}{0.010} \\
\hline \multirow[t]{2}{*}{2} & Negative & 8 & 19.5 & 33 & 80.5 & 41 & 100 & \\
\hline & Amount & 20 & 31.7 & 43 & 68.5 & 63 & 100 & \\
\hline
\end{tabular}

Table 4 is obtained findings that respondents who have effect normative positive tend to have the intention of stopping smoke i.e. $54.5 \%$. While negative normative beliefs tend not to have the intention to stop smoking which is $80.5 \%$.Statistical test results obtained $\mathrm{p}$ value $=0.010$ so that it can be seen that the working hypothesis (Ha) is accepted which means there is an influence of normative beliefs with the intention to stop smoking in the community in Kuta Paya Village, Seunagan District, Nagan Raya Regency in 2015.

Table 5. The Effect of Motivation Factors with Smoking Stop Intention in Respondents in Gampong Kuta Paya, Seunagan District, Nagan Raya Regency

\begin{tabular}{|c|l|c|c|c|c|c|c|c|}
\hline \multirow{3}{*}{ No } & \multirow{3}{*}{ Motivation } & \multicolumn{4}{|c|}{ Intention } & \multicolumn{2}{|c|}{$\begin{array}{c}\text { P } \\
\text { Have }\end{array}$} & \multicolumn{2}{|c|}{$\begin{array}{c}\text { Do not } \\
\text { have }\end{array}$} & \multicolumn{2}{|c|}{ Intention } & \multirow{2}{*}{ value } \\
\cline { 3 - 8 } & & $\mathrm{N}$ & $\%$ & $\mathrm{~N}$ & $\%$ & $\mathrm{~N}$ & $\%$ & \\
\hline 1 & There is & 12 & 52.2 & 11 & 47.8 & 23 & 100 & 0.018 \\
\hline
\end{tabular}




\begin{tabular}{|l|l|c|c|c|c|c|c|}
2 & $\begin{array}{l}\text { There is } \\
\text { no }\end{array}$ & 8 & 20.0 & 32 & 80.0 & 40 & 100 \\
\hline & Amount & 20 & 31.7 & 43 & 68.3 & 63 & 100
\end{tabular}

Table 5 shows that respondents there are motivation tends to have the intention to quit smoking namely $52.2 \%$. While those without motivation tend not to have the intention to quit smoking which is $80.0 \%$. Statistical test results obtained value of $\mathrm{p}$ value $=0.018$ so that it can be seen that the working hypothesis $(\mathrm{Ha})$ is accepted which means no influence motivation and intention to quit smoking in public in Kuta Gampong Paya Seunagan Sub Nagan Raya 2015.

Table 6. The Most Dominant Factor to Intention Stop Smoking in the Respondents in Kuta Paya Gampong Seunagan District, Nagan Raya Regency

\begin{tabular}{|l|c|c|c|}
\hline \multicolumn{1}{|c|}{ Variable affected } & $\mathrm{R}$ & $\mathrm{(OR})$ & $\mathrm{Cl} 95 . \%$ \\
\hline Attitude & 0.004 & 6.642 & $1.825-24.166$ \\
\hline Normative Belief & 0.128 & 2.840 & $0.739-10.910$ \\
\hline Motivation & 0.178 & 2.553 & $0.668-9.759$ \\
\hline Constant & 0.001 & 0.005 & \\
\hline
\end{tabular}

Based on table 6. shows that the most dominant factor influencing smoking intention is attitude; $r=0.004$ and OR of 6.6 means that the possibility of respondents who had positive attitude that is 6.6 times 1 money to have the intention to stop smoking. From these opportunities the possibility of having the smallest intention to stop smoking as much as 1.8 times that which has the greatest opportunity to have the intention to quit smoking as much as 24.1 times.

1. The effect of age on the intention to stop smoking in Respondents in Kuta Paya Village, Seunagan District, Nagan Regency Raya.

The test results obtained $\mathrm{P}$ value $>0.05$, ie there is no effect of age on the intention to quit smoking, and the researchers found that the higher the age, increasing dependency on cigarettes is also higher. The results of this study in accordance with the theory put forward that the nicotine in cigarette smoke is a substance that causes addiction or addiction, within seven seconds after the nicotine is inhaled it will soon reach the brain and cause a variety of reactions in nervous system [3]. If people have been smoking for many years with increasing age the nicotine levels in the blood become high enough that it is difficult to quit smoking [4].

\section{Effect offactor incomeagainst. Intention to} Quit Smoking pno respondents in Kuta Gampong Paya Seunagan Sub Nagan district Raya.

Test results obtained by the $\mathrm{P}$ value $>0.05$, the income do not affect the intention to quit smoking, the researchers found that a person's income above or below the UMP UMP does not affect the activity of smoking because of the high dependence of the effects caused by cigarettes that someone is trying at all costs smoking remains to be acquired by it. Moreover, supported also by the price of cigarettes ranging from cheapest to most expensive, making it easier for everyone is easy to get it in accordance with the income generated. According to Ayu [5] the problem of cigarette also be socio-economic issues. There are $60 \%$ of active smokers or by 84.84 million from 141.44 million people are those who come from poor or weak economy that daily difficulties in meeting their basic needs [6].

3. Effect of attitude factors on the intention to stop smoking in respondents in Kuta Paya Village, Seunagan Subdistrict, Nagan Raya Regency.

The test results obtained $\mathrm{P}$ values $<0.05$ researchers found respondents' attitudes affect the intention to quit smoking because of the positive attitude of the respondents to the intention to quit smoking, then the tendency to have a more positive intentions of quitting anyway. These findings are consistent with the theory [7] that the negative attitude towards smoking behaviour based on beliefs that smoking will give negative consequences for themselves, such as smoke can cause various health problems for smokers and people - the people around him [8]. Such beliefs can predict the intentions of quitting. Attitudes towards health risk behavior associated with a lower health risk behavior among them is smoking [9]

4. Factor Effect of the trust Normative Intention against Smoking Cessation the respondent in Gampong Kuta Paya Sub Seunagan district Nagan Raya.

The results of the test $P$ value $<0.05$, the researchers found, respondents normative beliefs affect the intention to quit smoking because if respondents believe that cigarettes have a positive impact for him then the tendency to not have the intention to quit smoking is higher and vice versa if the respondents believe that cigarettes can give a negative impact to himself then have the intention to quit smoking trend higher. These findings are consistent with the theory [10] is a normative belief is a belief in the opinions of others whether approve or disapprove of the actions to be taken.

5. The influence of motivational factors on the intention to stop smoking in respondents in Kuta Paya Village, Seunagan Subdistrict, Nagan Raya Regency. The test results obtained $\mathrm{P}$ values $<0.05$ researchers found respondents motivational effect on intentions to quit smoking because if the respondent has no motivation tend to have the intention to quit smoking, otherwise if the respondent no motivation then it tends to not have the intention to quit smoking. These findings are consistent with the theory [11] that motivation is a state within the individual or organism that drive behavior toward the goal, so it can be argued motivation has three aspects: a) the circumstances compelled within the organism, ie the readiness to move because physical needs, because of circumstances, or because of mental states such as thinking and memory, b) behavior directed arising due to these circumstances, and c) the goals or objectives pursued by such behavior[11], [12].

6. The results of the study found that the age of respondents was less productive $(38.1 \%)$, respondents worked as entrepreneurs $(34.9 \%)$, respondents had an 
[7] Budiharto, Behavioral Sciences and Health Education Dental Health, Jakarta: EGC 2005

filter-type cigarettes $(68.3 \%)$. Respondents had no intention $(68.3 \%)$, respondents were negative $(58.7 \%)$, respondents with negative normative beliefs $(65.1 \%)$, and respondents who had no motivation (63.5\%). Tatistic test results obtained no effect of age (P Value= 0.109), income $(\mathrm{P}$ Value $=1,000)$, with the intention to quit smoking, and there is an influence of attitude ( $\mathrm{P}$ Value $=0.001$ ), normative trust $(P$ Value $=0.010)$ and motivation $(P$ Value $=0.018)$ with the intention to stop smoking. The attitude that most influences intention $(\mathrm{OR}=6.6)$. It is hoped that this research can become input /information for health agencies and the community in increasing the intention to stop smoking in order to reduce the death rate from smoking.

\section{CONCLUSION}

Based on the results of research and discussion of the factors that influence the intention to stop smoking in the community in Kuta Paya Village, Seunagan District, Nagan Raya Regency, it can be concluded that: There is an influence of attitudes towards cessation intentions smoking, an influence of belief normative in the intention to stop smoking, a motivational effect in the intention to stop smoking and there was no effect of age on the intention to stop smoking in public in Kuta Gampong marsh Seunagan Sub Nagan Raya 2015 and factor the influence most domination smoking intentions is attitude

\section{REFERENCES}

[1] Ahsan, Abdillah, The influence of socioeconomic factors on individual smoking behavior: Analysis of data Susenas 2004Thesis: University of Indonesia, 2004.http://www.digilib.ui.ac.id/opac/themes/1 ibri2/detail.jsp?id=90281

[2] Files. UII, Theory basis intension Prososia 2012.http: // archive. UII. air conditioning. id / files / 2012/08 / 05. 2-chapter-293. pdf (26-082015).

[3] Astuti, K. Psychosocial Predictors of Adolescent Health Risk Behavior, Insight, II, 1, Yogyakarta: Wangsa University, 2012.

[4] Hall, Lisa Ellizabet, Stop Smoking, Yogyakarta: Garai science 2010

[5] Ayu, Z, W, Level Addiction Smoking and Smoking Cessation On Employee Motivation Dentistry Usu And public transportation Driver In Medan, Medan: 2014.

[6] Bashir, U. A cigarette left in doubt Why?. Jakarta: Pustaka At-taz 2005.
[8] _ Behavioral Sciences and Health Education Dental Health, Jakarta: EGC 2010

[9] Bungin, Burhan. Perception of active smokers in response to the warning labels to cigarettes, Jakarta, in 2007.http: // digilib. uin-like. air conditioning. id /.../ BAB\% 20i,\% 20IV,\% 20DAFTAR\% 20PUSTAKA [02-09-2015]

[10] BPOM. Adolescents, Cigarette and Tobacco, 2011. http: //ik. pom. go.id/ pdf (02-09-2015]

[11] Dreana MT, Analysis Influencing factors reception of Use simaweb, Semarang 2012.

[12] Diana D. Effect of Smoking Habits mouth mucosa. Dentika J Dent 2005

[13] Docdoc, Stop Smoking Program, 2015. https: // www. docdoc. com / en / en / info / procedure (26-08-2015)

[14] Fawzani, N. and Triratnawati, A, therapy to quit smoking (case study of heavy smokers). Makara, Health, 2005

[15] Hartono, Dhedy, CHAPTER II LITERATURE. Definition of age, 2004. http: // www. academia. Edu / 8899489 / 8_BAB_II_TINJAUAN_PUSTAKA \# signup / email. [15-09-2015]

[16] ILFA, Definitions Age, 2010, http: // ILFA. com / 2010/01 / definition -Age. html. [15-092015]

[17] John. Developmental Psychology, Jakarta: Kencana Prenada Media Group, 2011.

[18] MoH RI, Stop Smoking and Do not Get Started, Center for Health Promotion, Jakarta: Ministry of Health, 2007.

[19] Kholid, Ahmad., Health Promotion Behavior Theory Approach, Media And Its Application For Students and Practitioners Health, Jakarta: King Grafindo Persada, 2012.

[20] Indonesian Commission for Child Protection, Save the Children Of Danger Cigarette, web sites KPAI, 2013. 